\title{
Article \\ Effect of Epigallocatechin-3-Gallate on EGFR Signaling and Migration in Non-Small Cell Lung Cancer
}

\author{
Cristina Minnelli ${ }^{1, *,+} \oplus$, Laura Cianfruglia $2,+\oplus$, Emiliano Laudadio ${ }^{3} \oplus$, Giovanna Mobbili ${ }^{1} \oplus$, \\ Roberta Galeazzi ${ }^{1}$ (I) and Tatiana Armeni ${ }^{2, *(D)}$ \\ 1 Department of Life and Environmental Sciences, Marche Polytechnic University, 60131 Ancona, Italy; \\ g.mobbili@univpm.it (G.M.); r.galeazzi@univpm.it (R.G.) \\ 2 Department of Clinical Sciences, Marche Polytechnic University, 60131 Ancona, Italy; 1.cianfruglia@univpm.it \\ 3 Department of Science and Engineering of Matter, Environment and Urban Planning, Marche Polytechnic \\ University, 60131 Ancona, Italy; e.laudadio@staff.univpm.it \\ * Correspondence: c.minnelli@staff.univpm.it (C.M.); t.armeni@sunivpm.it (T.A.) \\ + Contributed equally to the work.
}

check for updates

Citation: Minnelli, C.; Cianfruglia,

L.; Laudadio, E.; Mobbili, G.;

Galeazzi, R.; Armeni, T. Effect of

Epigallocatechin-3-Gallate on EGFR

Signaling and Migration in

Non-Small Cell Lung Cancer. Int. J.

Mol. Sci. 2021, 22, 11833.

https://doi.org/10.3390/ijms222111833

Academic Editors: Jong Kook Park

and Young-Jun Jeon

Received: 10 September 2021

Accepted: 29 October 2021

Published: 31 October 2021

Publisher's Note: MDPI stays neutral with regard to jurisdictional claims in published maps and institutional affiliations.

Copyright: (c) 2021 by the authors. Licensee MDPI, Basel, Switzerland. This article is an open access article distributed under the terms and conditions of the Creative Commons Attribution (CC BY) license (https:// creativecommons.org/licenses/by/ $4.0 /)$.

\begin{abstract}
The epidermal growth factor receptor (EGFR) is one of the most well-studied molecular targets in non-small cell lung cancer (NSCLC) and tyrosine kinase inhibitors have been shown to be effective in the treatment of advanced NSCLC. Nevertheless, the efficacy of tyrosine kinase inhibitors could be compromised by additional mutations in EGFR and compensatory activations of other pathways. Epigallocatechin-3-gallate (EGCG), the main bioactive molecule in green tea, acts as a tyrosine kinase inhibitor toward cancer cells overexpressing EGFR (wild-type). However, little information has been reported on the effect of EGCG on EGFR with activating mutations. In this study, we evaluated the ability of EGCG to inhibit EGFR signaling activation in three different NSCLC cell lines containing wild-type EGFR or EGFR with additional mutations. The effect on proliferation, apoptosis, migration, and vinculin expression was then studied. Overall, our results demonstrate that EGCG polyphenol inhibits cell proliferation and migration in NSCLC cell lines, although with different efficacy and mechanisms. These data may be of interest for an evaluation of the use of EGCG as an adjunct to NSCLC therapies.
\end{abstract}

Keywords: epigallocatechin-3-gallate (EGCG); epidermal growth factor receptor (EGFR); tyrosine kinase inhibitors (TKIs); non-small cell lung cancer (NSCLC)

\section{Introduction}

Lung cancer is the leading cause of cancer-related death in the world, and nonsmall-cell lung cancer (NSCLC) accounts for $85 \%$ of cases, with most patients generally presenting, at the moment of diagnosis, an advanced lung cancer [1]. The highly invasive and metastatic potential can explain the high mortality rate (25\% of all cancer deaths). Many studies have shown that $90 \%$ of the NSCLC cases are characterized by overexpression and/or aberrant activation of epidermal growth factor receptor (EGFR) [2,3] which is a cell surface receptor tyrosine kinase to which growth factors selectively bind. Upon ligand binding, EGFR undergoes homo- or heterodimerization with other EGFR family receptors. This leads to the autophosphorylation of its tyrosine residues which serve as specific recruitment sites for downstream signaling molecules including mitogen-activated protein kinase (MAPK), a signal transducer and activator of transcription 3 (STAT3), and mammalian target of rapamycin (mTOR) (Figure 1A). As a result, EGFR, once triggered, acts as the initiator of the signal transduction process, stimulating cell growth and cell migration [4-7]. As a fact, EGFR overexpression, and/or mutations within the tyrosine kinase domain, lead to an overactivation of the downstream signaling pathways, playing an important role in epithelial cell transformation (Figure 1B). 


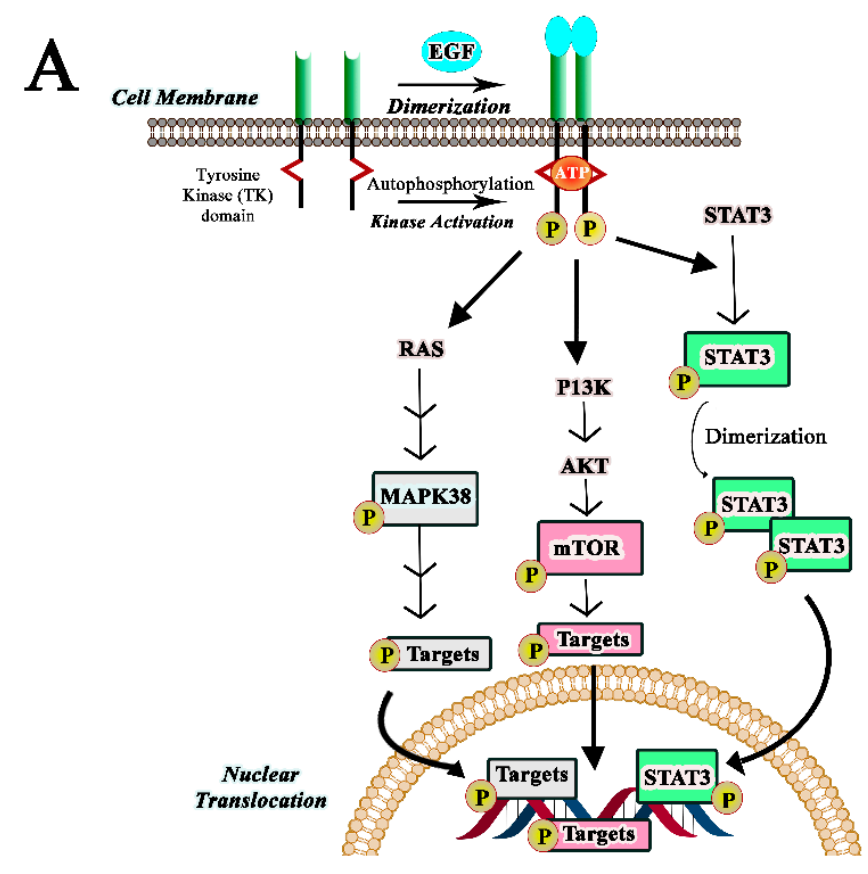

B

Wild type EGFR
Ligand-dependent activation

Ligand-dependent activation

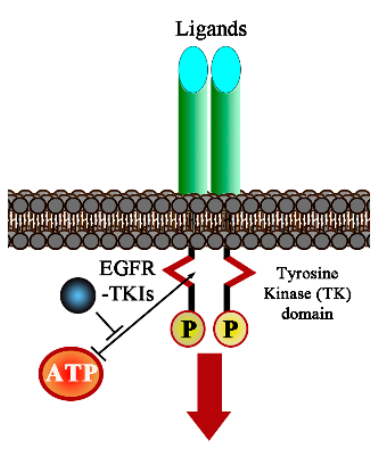

Mutant EGFR

Ligand-independent activation

Cell proliferation, motility, invasion, chemo/radiotherapy resistance

Figure 1. (A) Epidermal growth factor receptor (EGFR) pathway. The figure emphasizes the main signaling cascades: mitogen-activated protein kinase (MAPK), signal transducer and activator of transcription 3 (STAT3), and mammalian target of rapamycin (mTOR). (B) Differences between the activation mechanism of wild-type and mutant EGFR; the figure shows the role of tyrosine kinase inhibitors (TKIs) in the inhibition of EGFR by competing with ATP for the binding to the tyrosine domain kinase (TK).

NSCLC may have overexpressed wild-type or mutated EGFR form. Among the most common EGFR mutations in NSCLC are the in-frame deletion of exon 19 (EGFR ${ }^{\text {Del19}}$ ) and the point mutation in exon 21 (EGFR ${ }^{\mathrm{L} 858 \mathrm{R}}$ ) [8]. EGFR-tyrosine kinase inhibitors (EGFR-TKIs) such as gefitinib (Iressa ${ }^{\circledR}$ ) [9] have proven to be effective in the treatment of patients with advanced NSCLC harboring these EGFR mutations. Unfortunately, acquired resistance frequently occurs during the treatment. The $50-60 \%$ of resistant cases are caused by a secondary mutation on the gatekeeper residue of the ATP-binding pocket of EGFR (T790M, exon 20) [10] which seems to be more inclined to coexist with EGFR ${ }^{\mathrm{L} 858 \mathrm{R}}$ than with EGFR ${ }^{\text {Del19 }}$ [11].

Epigallocatechin-3-gallate (EGCG), is a bioactive catechin present in large quantities in green tea, which shows antiproliferative, anti-inflammatory, and antimutagenic properties [12-15]. In vitro research demonstrated that EGCG can inhibit the proliferation of 
lung cancer cells by influencing multiple signal transduction pathways [15,16]. Moreover, its ability to inhibit EGFR phosphorylation in lung cancer cells overexpressing wild-type EGFR (A549 cell lines) is well established [16]. Moreover, the co-administration of EGCG and Gefitinib synergically suppresses the tumor growth in the A549 xenograft mouse model [17].

However, little information has been reported on the effect of EGCG on the proliferation and migration of NSCLC harboring the in-frame deletion of exon 19 (EGFR ${ }^{\text {Del19}}$ ) and NSCLC with the secondary gatekeeper mutation T790M with oncogene driver L858R $\left(\right.$ EGFR $\left.^{\mathrm{L} 858 R / T 790 M}\right)$ [18]. In this study, we evaluate the efficacy of EGCG to inhibit the EGFR signaling pathway by studying the phosphorylation status of EGFR, mTOR, STAT3, and p38-MAPK in NSCLC harboring wild-type EGFR (A549 cell line), in-frame deletion of exon 19 mutation (HCC827 cell line), and L858R/T790M double mutation (H1975 cell line). In addition, the effects of EGCG on cell proliferation, migration, and apoptosis were also evaluated. Since migration and invasion of NSCLC are closely linked to changes in cytoskeleton organization, the effect of EGCG on the expression level of vinculin, the main constituent of focal adhesion, was also determined (Figure 2).

EGFR

Wild Type

Del-19, ELREA

L858R/T790M

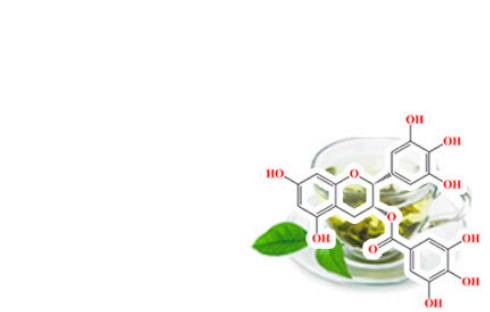

NSCLC Cell Lines

A549

HCC827

H1975
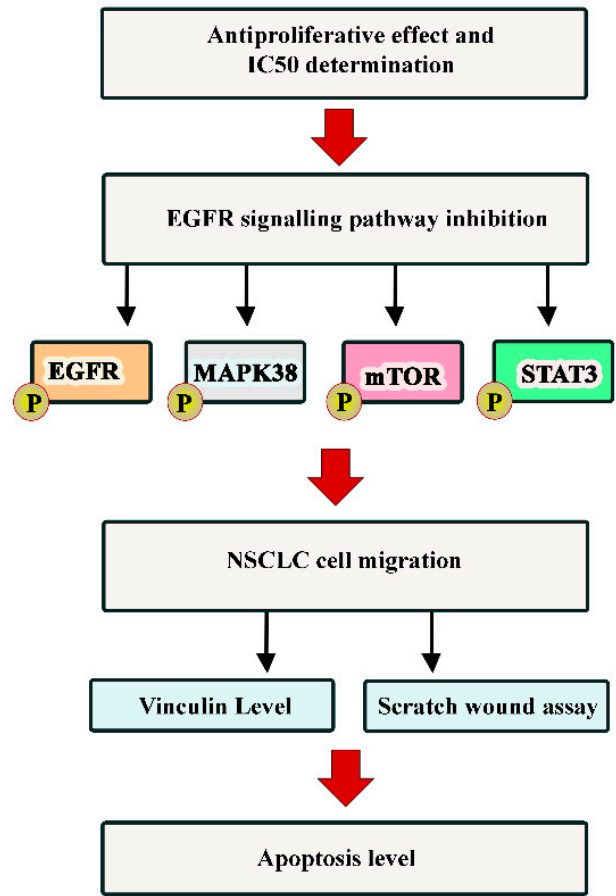

Figure 2. Schematic representation of the study.

\section{Results}

\subsection{Effect of EGCG on Viability of Different NSCLC Cell Lines}

The effect of EGCG on cellular metabolic activity (by MTT assay) was evaluated after $72 \mathrm{~h}$ of treatment with increasing EGCG concentrations. As shown in Figure 3, although the EGCG dose-dependently decreases the viability of all NSCLC cells, their sensitivity to EGCG treatment is different. A549 cells, with a wild-type EGFR sequence, show an IC50 of $70 \mu \mathrm{M}(\mathrm{SD} \pm 5)$. The other two cell lines are more resistant to EGCG treatment. In particular, the HCC 827 cells, which are characterized by an in-frame deletion in EGFR exon $19\left(\right.$ EGFR $\left.^{\text {Del19}}\right)$, show a two-fold increase in IC50 value with respect to the A549 cells (IC50, $143 \pm 8 \mu \mathrm{M}$ ). The H1975 cells, carrying a double EGFR mutation, display a higher drug resistance with an IC50 of $180 \mu \mathrm{M}(\mathrm{SD} \pm 7)$. Based on these results, we have chosen values near to $\frac{1}{2}$ IC50 as the three working EGCG concentrations (30, 70, and $\left.90 \mu \mathrm{M}\right)$ for the following experiments. 


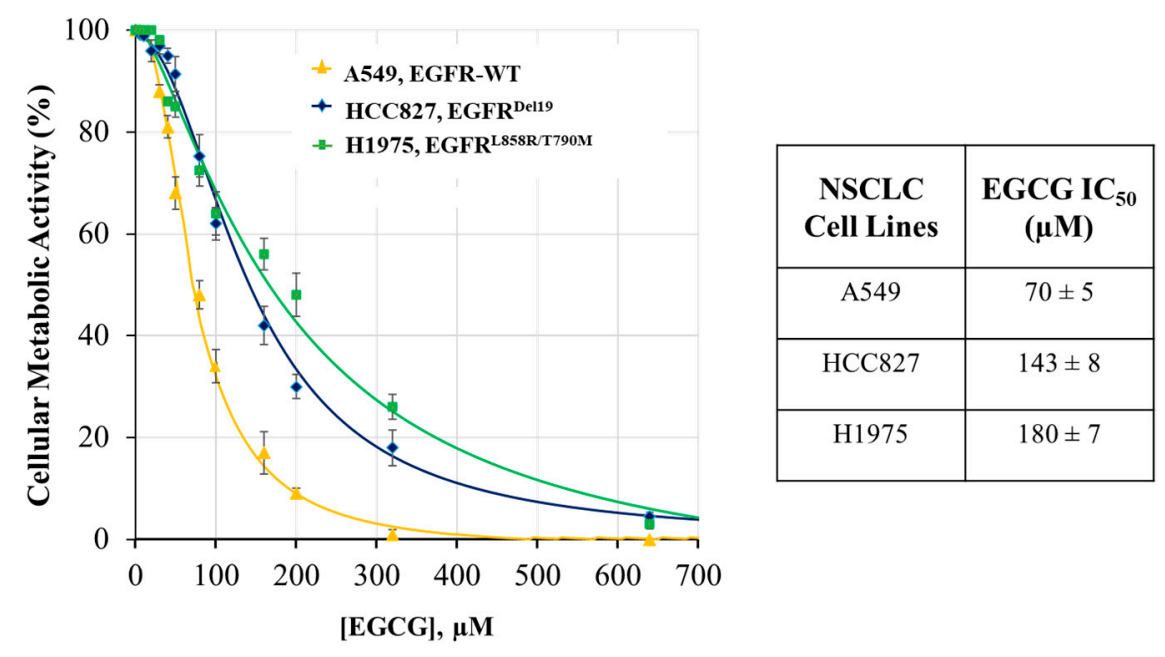

Figure 3. Effect of EGCG treatment on metabolic activity in NSCLC cells. Cell metabolic activity was determined by an MTT assay after exposure to an increasing concentration of EGCG for $72 \mathrm{~h}$. Cytotoxicity curves represent 5 experiments with 5 replicates for each EGCG concentration. Relative IC50 values shown were determined by non-linear regression using the SigmaPlot Software.

\subsection{EGCG Differentially Inhibits the EGFR Signaling Pathway}

In order to investigate how the EGFR mutations affect the ability of EGCG to inhibit the activation of EGFR signaling pathways, phosphorylation studies on EGFR, mTOR, STAT3, and MAPK38 have been performed (Figure 4).

As shown in Figure $4 \mathrm{~A}-\mathrm{C}$, the mutational status of EGFR directly influences the binding of EGCG, resulting in a different efficacy of the molecule in the inhibition of EGFR phosphorylation. In the A549 cell line, EGCG induces a dose-dependent decrease of EGFR phosphorylation reaching, at $90 \mu \mathrm{M}$, an inhibition of about $40 \%$ with respect to untreated cells $(p<0.05)$. The HCC 827 cells show the highest sensitivity with a 20\% decrease in EGFR phosphorylation already at $30 \mu \mathrm{M}$ EGCG which significantly increases in the presence of 70 and $90 \mu \mathrm{M}$ EGCG (40\% decrease with respect to untreated cells, $p<0.05)$. No effect of EGCG on EGFR inhibition has been observed in the H1975 cell line.

To determine the role of mTOR in EGFR signaling, western blotting of mTOR and phospho-mTOR has been performed. As shown in Figure 4C,D, ECGC induces a significant decrease in the phosho-mTOR/mTOR ratio in the HCC827 cell line (1.6- and 3.5-fold decrease of phospho-mTOR/mTOR ratio at 70 and $90 \mu \mathrm{M}$ EGCG concentrations, respectively) $(p<0.05)$. In A549 cells, 30 and $70 \mu \mathrm{M}$ EGCG induce a significant reduction in the phospho-mTOR/mTOR ratio (twofold decrease with respect to untreated cells, $p<0.05$ ). Although EGCG induces a decrease in mTOR expression and mTOR phosphorylation, the phospho-mTOR/mTOR ratio remains unchanged in H1975 cells (Figure 4D,E).

The inhibition of STAT3 signaling was observed only for the HCC827 cell line in which there is a decrease in phospho-STAT3/STAT3 ratio, at 70 and $90 \mu \mathrm{M}$ EGCG concentration, of about three times with respect to untreated HCC827 cells $(p<0.05)$. No effect is present for the other two NSCLC cell lines.

Expression of p38 MAPK is affected by EGCG treatment only in the A549 cells at $90 \mu \mathrm{M}$ EGCG (twofold decrease with respect to untreated cells, $p<0.05$ ); the phosphorylated form of p38 MAPK (phospho-p38 MAPK) is present only in the HCC827 cell line (Figure 4D). In fact, as just described, phospho-p38MAPK is usually poorly detectable in cells [19]. HCC827 cells did not show any significant changes in the p38 MAPK expression but a strong reduction in its phosphorylated form is observed after $24 \mathrm{~h}$ of treatment with 70 and $90 \mu \mathrm{M}$ EGCG concentrations (fourfold decrease with respect to untreated cells, $p<0.05$ ). 
A

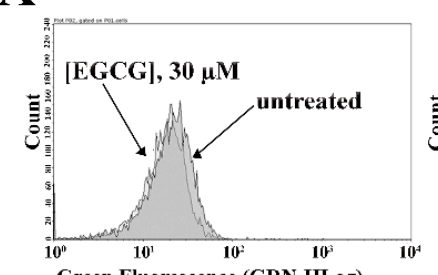

B
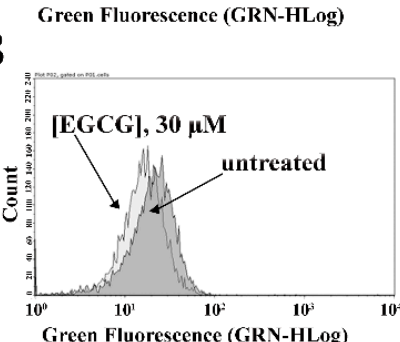

C

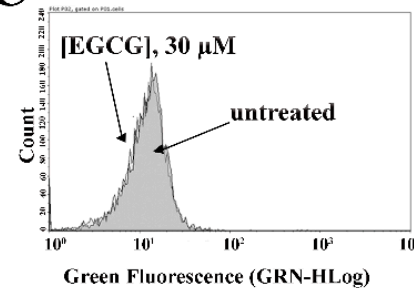

Green Fluorescence (GRN-HLog)

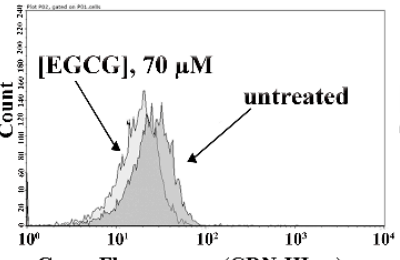

Green Fluorescence (GRN-HLog)

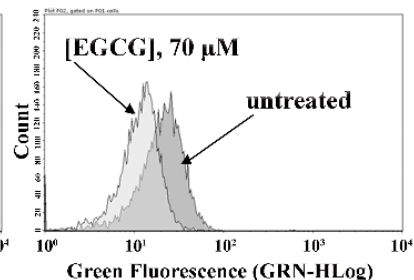

Green Fluorescence (GRN-HLog)

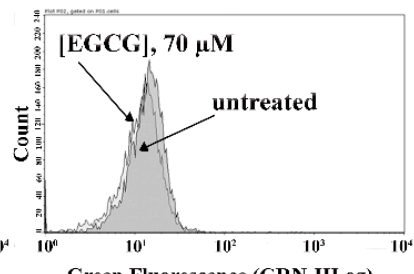

Green Fluorescence (GRN-HLog)

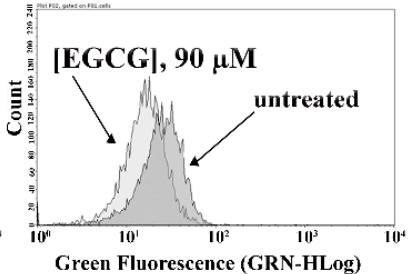

Green Fluorescence (GRN-HLog)
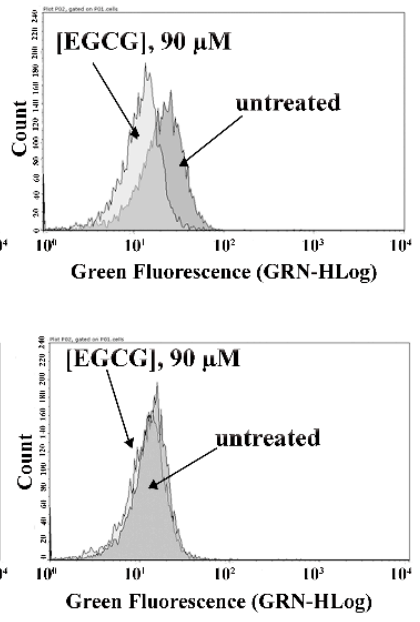

$\mathrm{E}$

D

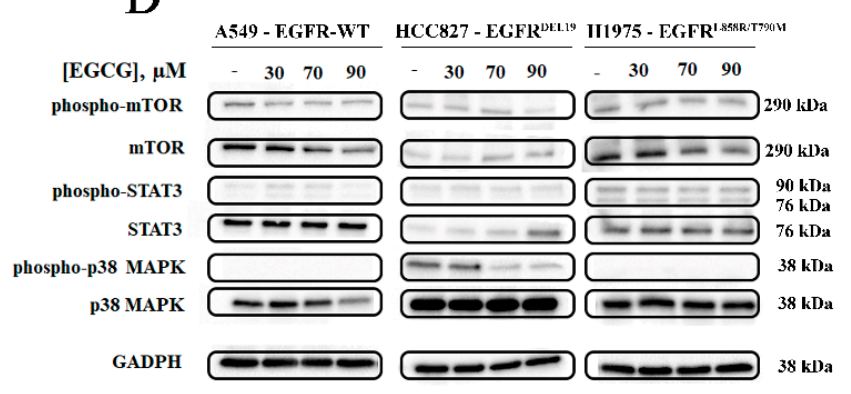

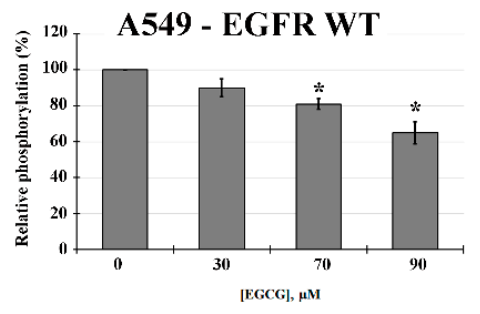

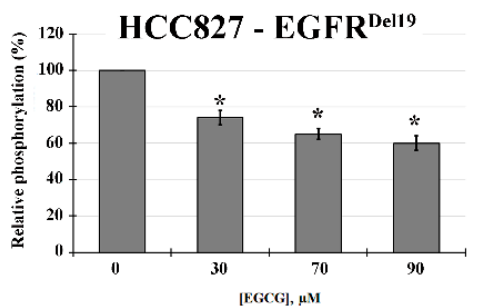

H1975 - EGFR ${ }^{\text {L858R/T790M }}$
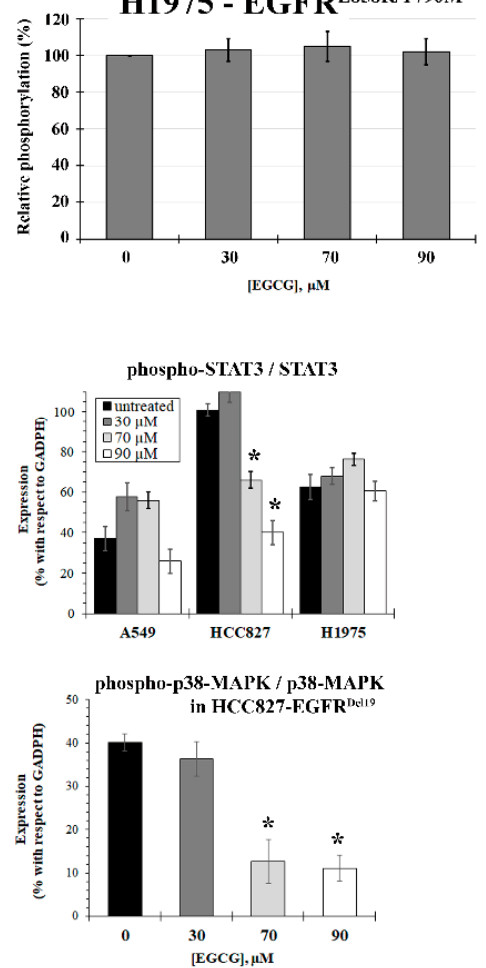

Figure 4. The effect of EGCG on the EGFR signaling pathway. (A) A549, (B) HCC827, and (C) H1975 cells after different EGCG treatments $(30,70$, and $90 \mu \mathrm{M})$ for $24 \mathrm{~h}$ and analyzed by flow cytometry after staining with antibodies against EGFR and phospho-EGFR (Y1068). On the left, is shown representative FACS (fluorescence-activated single-cell sorting overlay plots) depicting phospho-EGFR levels after EGCG treatment. The histograms on the right represent the percentages of Y1068 EGFR phosphorylation normalized to total EGFR levels. The data was calculated by dividing the geometric mean fluorescence intensity of phopho-EGFR by the geometric mean fluorescence intensity of the total EGFR. (D) Immunoblot analysis for A549, HCC827, and H1975 cells treated with different EGCG concentrations (30, 70, and $90 \mu \mathrm{M})$. Cells were lysed $24 \mathrm{~h}$ after exposure to EGCG, then extracts were analyzed by western blot with anti-STAT3, anti-phospho-STAT3, antimTOR, anti-phospho-mTOR, anti-p38 MAPK, and anti-phospho-p38 MAPK antibodies. GAPDH was used as an internal loading control. (E) Densitometric analysis of the ratio between phospho-mTOR/mTOR and phospho-STAT3/STAT3; p38-MAPK expression and phospho-p38-MAPK/p38-MAPK ratio in HCC827 cells. All results are normalized to GAPDH. ${ }^{*} p<0.05$. For p38-MAPK and phospho-p38-MAPK, a longer exposure time was used (15 s). Full-length blots are presented in Supplementary Figure S1. The samples were derived from the same experiment and the blots were processed in parallel. 


\subsection{EGCG Differentially Affects Cellular Migration and Vinculin Expression}

To understand the effect of EGCG on NSCLC cell migration, an in vitro scratch model was used, and the results were expressed as a percentage of wound closure. Treatments have been evaluated after 48 and $72 \mathrm{~h}$ in the presence of the selected EGCG concentrations (Figure 5).

\section{A}
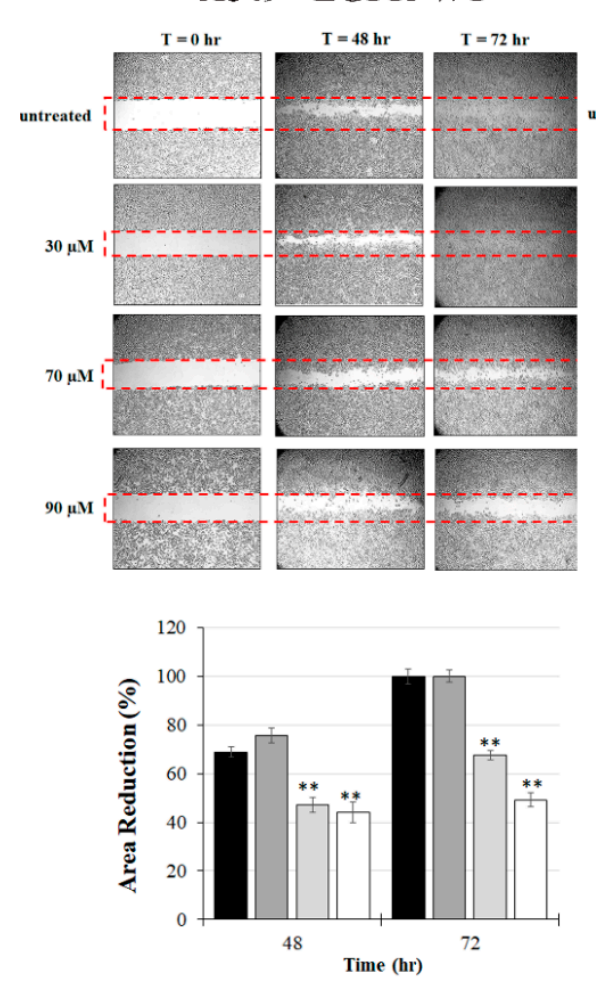

antreated $\square 30 \mu \mathrm{M} \quad \square 70 \mu \mathrm{M} \quad \square 90 \mu \mathrm{M}$
B
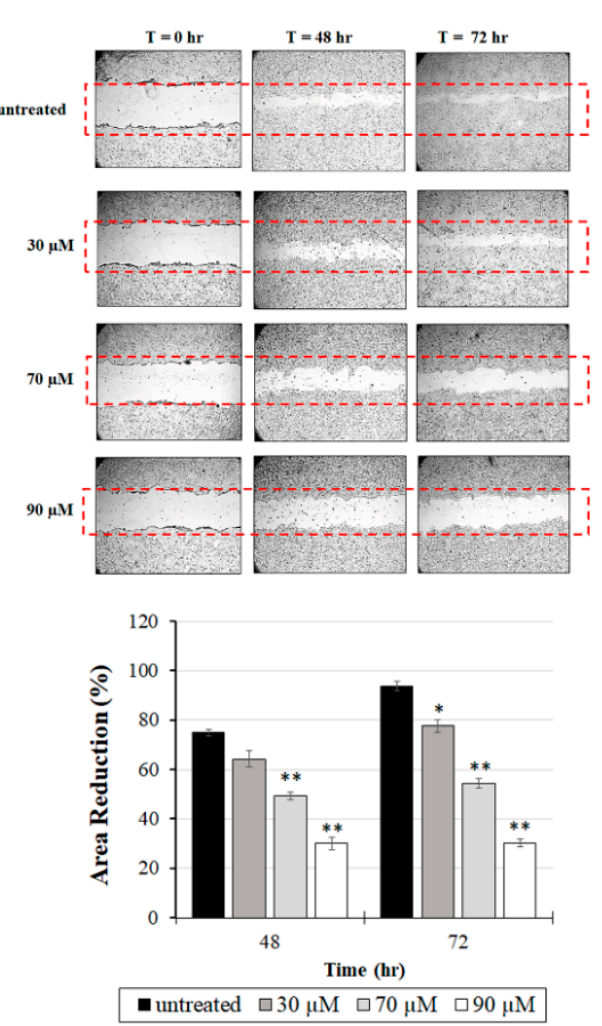

\section{H1975 - EGFR ${ }^{\text {L858R/T790M }}$}
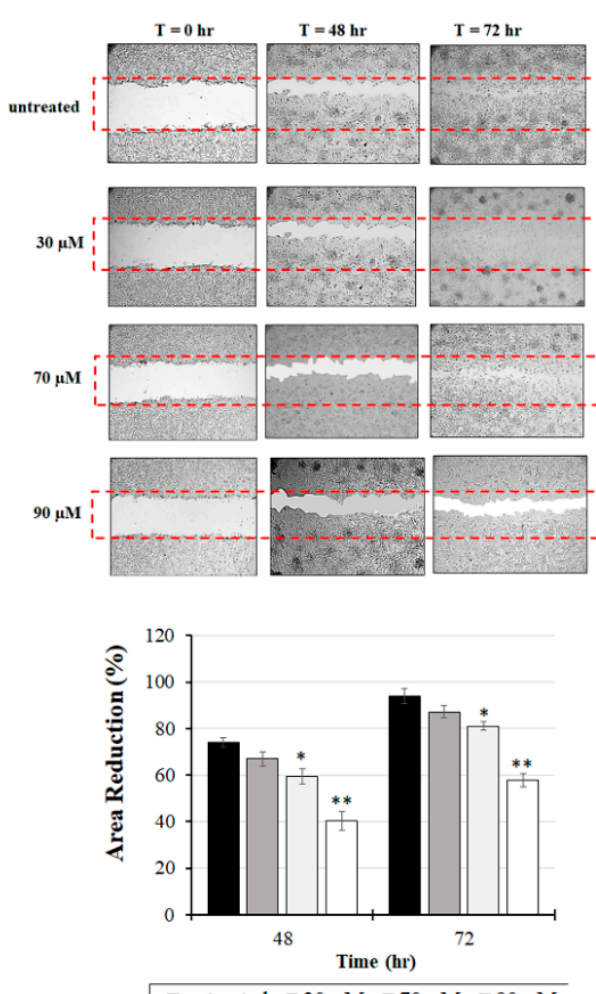

- untreated $\square 30 \mu \mathrm{M} \quad \square 70 \mu \mathrm{M} \quad \square 90 \mu \mathrm{M}$
D

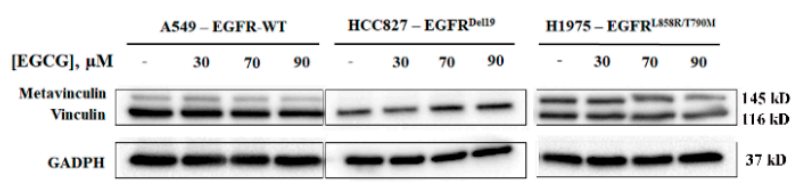

$\mathbf{E}$

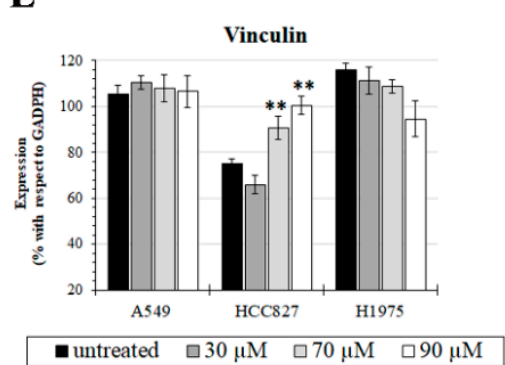

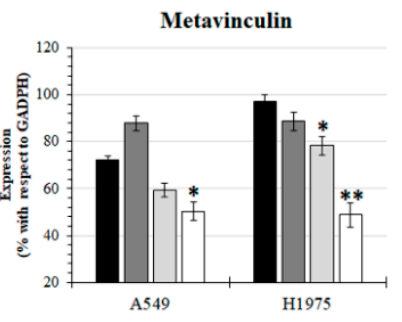

- untreated $\square 30 \mu \mathrm{M} \square 70 \mu \mathrm{M} \square 90 \mu \mathrm{M}$

Figure 5. The effect of EGCG on NSCLC cell migration. (A) A549, (B) HCC827, and (C) H1975 cell migration after different EGCG treatments $(30,70$, and $90 \mu \mathrm{M})$ was evaluated by scratch wound assay. Images were taken at times 0,48 , and $72 \mathrm{~h}$. The wound area was measured by ImageJ software. The percentage migration was calculated by the average area reduction at 24,48 , and $72 \mathrm{~h}$ as compared to time 0 . The red dotted box represents the size of the original wound. The data is the mean of triplicate experiments \pm SD. Scale bar: $100 \mu \mathrm{m}$. (D) Representative Western blot experiment depicting total vinculin and metavinculin expression after $24 \mathrm{~h}$ of EGCG treatment. (E) Densitometric analysis showed differences in vinculin expression. GAPDH was used as an internal loading control. ${ }^{*} p<0.05 ;{ }^{* *} p<0.01$. GAPDH is the same as Figure 4 D as the blots were derived from the same membrane incubated with different antibodies. Full-length blots are presented in Supplementary Figure S1. The samples were derived from the same experiment and the blots were processed in parallel.

After $72 \mathrm{~h}$ of $30 \mu \mathrm{M}$ EGCG treatment, the migratory ability of A549 cells is not affected while, at $70 \mu \mathrm{M}$ EGCG, it is significantly retarded by $33 \%$ when compared to untreated cells 
$(p<0.05)$. The inhibition effect further increases in the presence of $90 \mu \mathrm{M}$ concentration where the wound closure decreases by $52 \%$ after $72 \mathrm{~h}$ of treatment $(p<0.05)$. In the H1975 cell line, EGCG has a dose-dependent effect on cellular migration. In particular, after $72 \mathrm{~h}$ of treatment with 70 and $90 \mu \mathrm{M}$ EGCG, the percentage of area decreases by 20 and $40 \%$, with respect to reference control value, respectively $(p<0.05)$. In contrast, EGCG strongly affects the migratory ability of HCC 827 cells, with a marked dose-dependent effect. After $72 \mathrm{~h}$ of treatment, EGCG $30 \mu \mathrm{M}$ induces an inhibition of $20 \%$ in the migration rate while, at $70 \mu \mathrm{M}$, EGCG retards the wound closure by $45 \%$. Interestingly, at $90 \mu \mathrm{M}$, the cell migration rate is completely arrested and the wound area is the same at 48 and $72 \mathrm{~h}$ of treatment while only $30 \%$ of cells migrated in the wound with respect to untreated cells (Figure 4).

Since the speed of wound closure depends, in addition to cell proliferation index, on cytoskeleton reorganization, the impact of EGCG on the expression of vinculin (Vnc) was studied by immunoblot results (Figure 5D,E). The anti-vinculin antibody detects two isoforms of Vnc in A549 and H1975 cell lines, vinculin (116 kDa) and metavinculin $(145 \mathrm{kDa})$, resulting in two bands on the immunoblot. Although no effect is observed in the Vnc expression after EGCG treatment, a reduction in metavinculin $(\mathrm{mVnc})$ expression is observed. In particular, at $90 \mu \mathrm{M}$, EGCG causes a significant decrease in mVnc expression of about twice in H1975 cells with respect to untreated cells $(p<0.01)$. A similar effect is observed in the A549 cells with a 1.5-fold decrease in mVnc expression $(p<0.05)$. Interestingly, the mVnc isoform is not revealed in HCC827. Furthermore, in this case, EGCG significantly increases the Vnc expression level already at $70 \mu \mathrm{M}$ of about twice with respect to control $(p<0.01)$.

\subsection{EGCG Treatment Induces an Increase in NSCLC Apoptosis Level}

To detect apoptosis, Annexin V-FITC, a calcium-dependent phosphatidylserine-binding protein, has been used. During both early and late apoptosis, apoptotic cells or bodies translocate phosphatidylserine to the outer leaflet of the plasma membrane; therefore, fluorescent Annexin V conjugate can detect cells at different apoptotic stages. Figure 6 shows the apoptosis levels of the three NSCLC cell lines untreated or treated with the different concentrations of EGCG after $72 \mathrm{~h}$.

Untreated A549 cell lines show 95\% live cells with an intact physical shape whereas the cells treated with EGCG show significantly increased cell death rates already at $30 \mu \mathrm{M}$ with $14 \%$ of early apoptotic cells and $3 \%$ of late apoptotic cells. The concentrations of 70 and $90 \mu \mathrm{M}$ cause an even greater increase in the percentage of early apoptotic cells to $18 \%$.

HCC827 cells show a dose-dependent increase in apoptosis levels. Indeed, at $30 \mu \mathrm{M}$ EGCG, there is an increase in the percentage of apoptotic cells, from $3 \%$ of untreated cells to $10 \%$. At $70 \mu \mathrm{M}$ of EGCG concentration, the percentage of cells undergoing apoptosis reaches $15 \%$, of which $11 \%$ undergo early apoptosis and $4 \%$ late apoptosis. The $90 \mu \mathrm{M}$ concentration of EGCG further increases the percentage of cells in apoptosis with respect to untreated cells (23\%); a significant increase in late apoptosis is observed.

H1975 cells are also sensitive to the treatment with $90 \mu \mathrm{M}$ EGCG, which significantly increases the rate of apoptosis to $19 \%$ mainly by early apoptosis induction. 
A

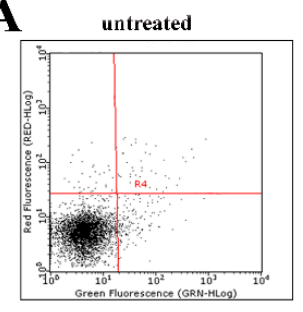

B

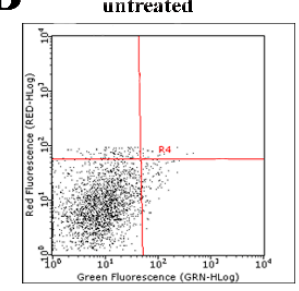

C

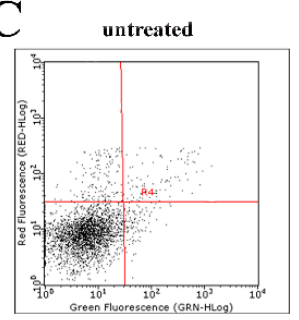

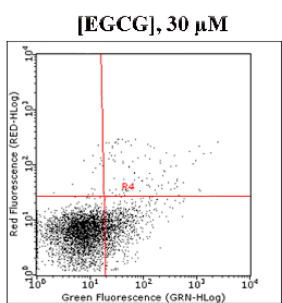

[EGCG], $30 \mu \mathrm{M}$

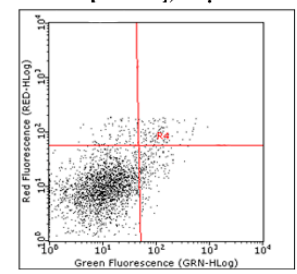

[EGCG], $30 \mu \mathrm{M}$

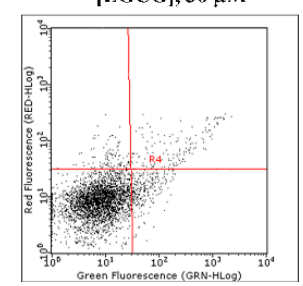

[EGCG], $70 \mu \mathrm{M}$

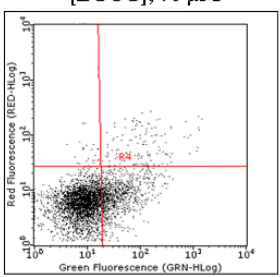

[EGCG], $70 \mu \mathrm{M}$

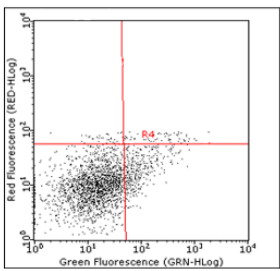

[EGCG], $70 \mu \mathrm{M}$

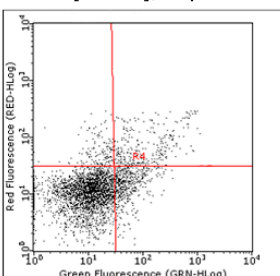

[EGCG], $90 \mu \mathrm{M}$

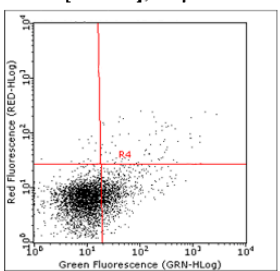

[EGCG], $90 \mu \mathrm{M}$

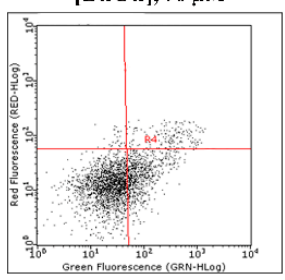

[EGCG], $90 \mu \mathrm{M}$

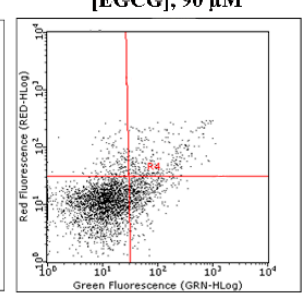

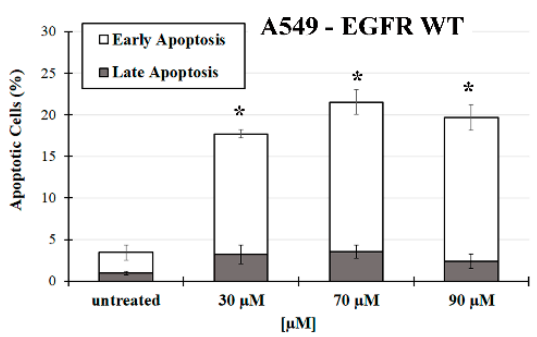
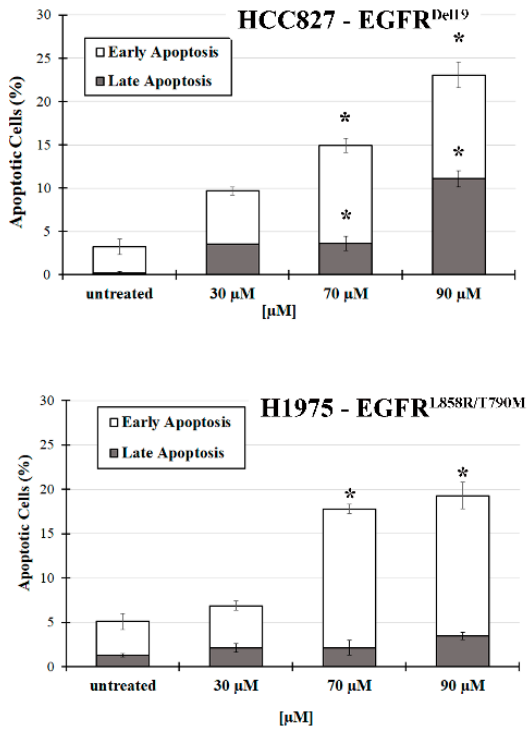

Figure 6. The effect of EGCG on NSCLC apoptosis level. Flow cytometry analysis of (A) A549, (B) HCC827, and (C) H1975 cells after $72 \mathrm{~h}$ with different EGCG treatments (30, 70, and $90 \mu \mathrm{M})$ using Annexin V/FITC and PI double stain. GRN-HLog refers to the green fluorescence intensity (FITC channel) and RED-HLog to the red fluorescence intensity (PI channel). On the left there are representative cytograms in which R4 indicates the markers used for the analysis to identify the state of the cells: viable (Annexin V-PI-), early apoptotic (Annexin V+PI-), late apoptotic (Annexin V+PI+), and necrotic (Annexin $\mathrm{V}-\mathrm{PI}+)$ cells. The histograms on the right represent the percentages of early and late apoptosis. The data is the mean of triplicated experiments \pm standard deviation. ${ }^{*} p<0.05$.

\section{Discussion}

Concerning the EGFR overexpression or mutation, there is a constitutive activation of EGFR downstream signaling pathways, which include PI3K/AKT/mTOR pro-survival, STAT3 transcription factor, and RAS/MAPK proliferation pathways [20,21]. Once activated, this complex network of cellular signal transducers induces cell proliferation, survival, and cell migration. Therefore, in NSCLC stimulation of proliferation and survival is induced by mutated EGFR, which is constitutively active. Since its function is finely regulated by reversible protein phosphorylation, tyrosine kinase inhibitors (TKIs) are widely used in the treatment of NSCLC. However, although some studies have shown very high response rates of EGFR-mutant tumors to TKIs, direct and/or indirect resistance mechanisms could interfere with the efficacy of the latest TKIs. Known resistance mechanisms involve a secondary mutation (T790M) and a tertiary mutation (C797S) in patients treated with gefitinib and osimertinib, respectively. In addition, compensatory activations of downstream EGFR pathways, such as MAPK, STAT3, and mTOR, could bypass the EGFR signaling inhibition [22,23]. It is therefore an urgent need to discover molecules able to bypass these resistance mechanisms reinforcing the efficacy of TKIs. We studied the effect of EGCG on proliferation, apoptosis, and EGFR signaling (mTOR, MAPK38 and STAT3) in three NSCLC cell lines harboring an in-frame deletion of exon $19\left(\mathrm{EGFR}^{\text {Del19 }}\right)$, double mutations T790M/L858R (EGFR ${ }^{\text {L858R/T790M }}$ ), and wild-type EGFR. Since cell motility has been shown 
to be an integral process in early lung cancer ontogeny, we studied the ability of EGCG to prevent NSCLC migration with respect to the expression of vinculin (Vnc) [24,25].Vnc is a well-known actin-binding protein involved in focal adhesion development acting as a tumor suppressor protein in cancer including in NSCLC [26]. Low Vnc expression is associated with an increased metastatic potential [26-29].

Our findings show a different sensitivity of NSCLC proliferation toward EGCG treatment (A549 > HCC827 > H1975) (Figure 3) which could be attributed in part to the different ability of EGCG to inhibit EGFR signaling. In wild-type EGFR cells (A549) and in those harboring exon 19 deletion (HCC827), EGCG efficiently inhibits the TK phosphorylation. The results obtained confirm our previous in silico data in which we showed the molecular mechanism of kinase inhibition by EGCG in wild-type EGFR, EGFR ${ }^{\text {Del19 }}$, and in double mutant EGFR ${ }^{\mathrm{L} 858 \mathrm{R} / \mathrm{T} 790 \mathrm{M}}$ cells [30]. After the EGFR structure modeling, the estimation of the free-binding energy of EGCG to EGFR-tyrosine kinase domain had been extrapolated using the molecular mechanics with the Poisson-Boltzmann surface area solvation (MM/PBSA) method [31]. The presence of L858R and T790M mutations partially hinders the EGCG binding inside the ATP-binding pocket and therefore the EGCG affinity toward

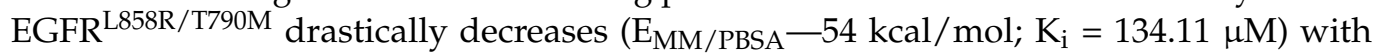
respect to the wild-type EGFR $($ EMM $/$ PBSA — $98 \mathrm{kcal} / \mathrm{mol} ; \mathrm{Ki}=0.13 \mu \mathrm{M})$. Deletion of the five amino acids in the ATP-binding pocket $\left(E_{G F R}{ }^{\text {del19}}\right)$ leads instead to the formation of additional polar interactions increasing the EGCG binding affinity with respect to $\mathrm{EGFR}^{\mathrm{L} 858 \mathrm{R} / \mathrm{T} 790 \mathrm{M}}$ (EMM/PBSA-75 kcal $/ \mathrm{mol} ; \mathrm{Ki}=0.84 \mu \mathrm{M}$ ) [30].

The difference is also found in the phosphorylation of downstream EGFR proteins (Figure 4D,E). In H1975 cells, where the EGFR phosphorylation status is not inhibited by EGCG, the ratio between the phosphorylated form of STAT3 and mTOR and their corresponding total protein does not change with respect to untreated cells. The EGFR signaling pathway is therefore in an active state in presence of EGCG. These results indicate that the treatment of EGFR ${ }^{\mathrm{L} 858 \mathrm{R} / \mathrm{T} 790 \mathrm{M}}$ positive NSCLC patients would not strengthen the TKIs efficacy. However, at 70 and $90 \mu \mathrm{M}$ of EGCG, a significant induction of apoptosis is observed in the H1975 cell line (Figure 6), probably due to the inhibition of other pathways. EGCG is in fact a pleiotropic molecule able to interact with several biological targets. Moreover, after $72 \mathrm{~h}$ of treatment, EGCG $(90 \mu \mathrm{M})$ strongly reduces the migration of H1975 cells with an inhibition of wound closure of about $40 \%$ with respect to untreated cells, and this could be related to a decrease in the expression of meta-vinculin ( $\mathrm{mVnc}$ ) (Figure 5). This is a Vnc splice isoform that contains an additional exon encoding a 68-residue insert within the actinbinding tail domain. Similarly to Vnc, $\mathrm{mVnc}$ can engage filamentous (F)-actin, but only vinculin can promote F-actin bundling [32-34]. Moreover, several studies have shown that $\mathrm{mVnc}$ can negatively regulate Vcn-mediated F-actin bundling in vitro. This novel finding could explain the EGCG-induced decrease in cellular migration in addition to the apoptosis induction. Overall, EGCG suppresses cell proliferation independently of EGFR signaling pathway inhibition in the H1975 cell line while inducing a significant decrease in cell migration.

As just reported [35], the inhibition of EGFR phosphorylation in A549 cells, overexpressing wild-type EGFR, results in the inhibition of mTOR which is a key intracellular kinase involved in the regulation of proliferation and cell survival $[36,37]$. The mTOR blockade, therefore, interferes at multiple levels with tumor growth, and the dual targeting of EGFR and mTOR may have a greater effect with respect to the administration of a single target [4]. However, STAT3, which is persistently activated in 22-65\% of NSCLC [20,38], remains in an active state. Overall, the inhibition of the EGFR signaling pathway can be responsible for the inhibition of cell growth and apoptosis activation seen in the A549 cells. Cellular migration is reduced only at IC50 EGCG concentration or more (70 and $90 \mu \mathrm{M}$ ). Additionally, in this case, the decrease in mVnc could be involved in the observed decline in cell motility (Figure 5). The most EGCG-responsive NSCLC, in terms of both signaling pathway activation and cell migration, is, however, the HCC827 cell line in which all analyzed EGFR downstream pathways, from mTOR to MAPK38, are suppressed. 
Considering that the use of TKIs induces STAT3 and MAPK38 activation [39-41], the use of EGCG as an adjuvant drug can effectively increase the efficacy of TKIs in this specific type of NSCLC. The inhibition of these pathways affects cell proliferation, explaining the higher impact that EGCG treatment elicits in HCC827 cells. Moreover, in these NSCLC cells, migration is arrested at all EGCG concentrations tested and, only for this NSCLC cell line, a significant reduction in Vnc is observed, therefore lowering its invasive and metastatic potential.

\section{Materials and Methods}

\subsection{Reagents}

Cell culture reagents were obtained from Euroclone (Milan, Italy). Chemical reagents and propidium iodide (PI) were obtained from Sigma-Aldrich (St. Louis, MO, USA). Annexin V-FITC apoptosis detection kit was obtained from Biolegend (San Diego, CA, USA). Chemiluminescent substrate and secondary antibody (32460) were obtained from Thermo Fisher Scientific (Waltham, MA, USA). Bradford reagent and polyvinylidene difluoride (PVDF) membranes were obtained from Bio-Rad (Hercules, CA, USA).

\subsection{Cell Culture}

The human non-small cell lung cancer (NSCLC) cell lines were all obtained from the American Type Culture Collection (ATCC). The H1975 (CRL-5908 ${ }^{\mathrm{TM}}$ ) and HCC827 (CRL-2868 ${ }^{\mathrm{TM}}$ ) cell lines were grown in RPMI 1640 medium (ECB2000) supplemented with $10 \%$ fetal bovine serum (FBS), $2 \mathrm{mM}$ L-glutamine, $100 \mathrm{U} / \mathrm{mL}$ penicillin, and $100 \mu \mathrm{g} / \mathrm{mL}$ streptomycin while the A549 (CCL-185 ${ }^{\mathrm{TM}}$ ) was grown in complete DMEM/F12 medium (ECM0095). All cell lines were routinely maintained in $75 \mathrm{~cm}^{2}$ flasks at $37{ }^{\circ} \mathrm{C}, 5 \% \mathrm{CO}_{2}$, and $95 \%$ relative humidity. The cell cultures were detached by trypsinization with $0.5 \%$ trypsin in PBS containing $0.025 \%$ EDTA and counted using trypan blue exclusion assay. All cell culture reagents were supplied by Euroclone. For all treatments, EGCG was freshly prepared in deionized water at a concentration of $12 \mathrm{mM}$.

\subsection{Cell Viability Assay}

The number of metabolically active cells, and thus cell viability, was assessed by a 3-(4,5dimethylthiazol-2-yl)-2,5-diphenyltetrazolium bromide (MTT) assay [12,42]. The NSCLC cell lines (A549, H1975, and HCC827) were seeded in 24-well plates to reach 50\% confluence at $24 \mathrm{~h}$; then, the medium was removed and replaced with $1 \mathrm{~mL}$ of fresh culture medium containing increasing EGCG concentrations $(0-640 \mu \mathrm{M})$. After $72 \mathrm{~h}$, the medium from each well was removed and replaced with fresh medium supplemented with MTT at a final concentration of $100 \mu \mathrm{g} / \mathrm{mL}$, and the NSCLC cells were incubated for $3 \mathrm{~h}$ at $37^{\circ} \mathrm{C}$ in a $5 \%$ $\mathrm{CO}_{2}$ atmosphere. Then $0.4 \mathrm{~mL}$ of DMSO was added to each well to solubilize the purple formazan crystals formed from MTT reduction. The absorbance was read on a multiwell scanning microplate reader (BioTek Synergy HT MicroPlate Reader Spectrophotometer, BioTek Instruments Inc., Winooski, VT, USA) at $570 \mathrm{~nm}$ using the extraction buffer as a blank. The optical density in the control group (untreated cells) was considered as $100 \%$ viability. The relative cell viability $(\%)$ was calculated as $\left(\mathrm{OD}_{570}\right.$ of treated samples/OD $\mathrm{OD}_{570}$ of untreated samples) $\times 100$. Dose-dependent curves were therefore generated for the cytotoxic studies. The 50\% inhibiting concentration (IC50) was determined by non-linear regression analysis with a three-parameter fit by utilizing SigmaPlot 12.0 Software. Each experiment was performed at least five times in triplicate.

\subsection{EGFR Phosphorylation Studies by Flow Cytometry}

The effect of EGCG on EGFR phosphorylation inhibition was evaluated by flow cytometry. For induction of EGFR phosphorylation, A549 cells were incubated for $20 \mathrm{~min}$ with $50 \mathrm{ng} / \mathrm{mL}$ recombinant EGF (Euroclone), before EGCG treatment. The NSCLC cell lines were treated with 30,70, and $90 \mu \mathrm{M}$ EGCG for $4 \mathrm{~h}$. Cells were harvested by incubation with $0.25 \%$ trypsin-EDTA and fixed for $20 \mathrm{~min}$ at room temperature (R.T.) with 
$2 \%$ paraformaldehyde. Before the staining with antibodies against EGFR (Invitrogen, MA528104) and phospho-EGFR (Y1068) (R\&D System, IC3570F), the cells were permeabilized for $30 \mathrm{~min}$ on ice in PBS, $0.5 \%$ BSA and $0.025 \%$ Triton X100. Anti-EGFR and anti-phosphoEGFR were incubated for $1 \mathrm{~h}$ in the dark at $4{ }^{\circ} \mathrm{C}$. At least 5000 cells for each sample were measured using the same settings. For inhibiting potential phosphatase activity, the staining and permeabilization buffers were supplemented with sodium fluoride $(\mathrm{NaF})$ and sodium orthovanadate $\left(\mathrm{Na}_{3} \mathrm{VO}_{4}\right)$ to a final concentration of $1 \mathrm{mM}$. The percentage of EGFR phosphorylation was calculated by dividing the geometric mean fluorescence intensity of phospho-EGFR by the geometric mean fluorescence intensity of the EGFR.

\subsection{Apoptosis Assay}

Apoptosis was analyzed by flow cytometry using Annexin V-FITC apoptosis detection kit (Biolegend), according to the manufacturer's instructions. A549, HCC827, and H1975 cells were treated with different EGCG concentrations (30, 70, and $90 \mu \mathrm{M})$. The analysis was performed after $72 \mathrm{~h}$. Briefly, control and treated cells were trypsinized, washed twice with ice-cold PBS, and resuspended in $1 \mathrm{X}$ Annexin binding buffer at a final concentration of $1.0 \times 10^{6}$ cell $/ \mathrm{mL}$. Annexin V-FITC $(0.25 \mu \mathrm{g} / \mathrm{mL})$ and PI $(1 \mu \mathrm{g} / \mathrm{mL})$ were added to the cell suspension and the mixture was incubated for $15 \mathrm{~min}$ at R.T. in the dark [35]. Samples were analyzed using the Guava EasyCyte flow cytometer (Millipore) at an excitation wavelength of $488 \mathrm{~nm}$. A total of 5000 events were acquired for each sample. Annexin V-FITC was detected as a green fluorescence and PI was detected as a red fluorescence. Early apoptosis is defined by Annexin V+/PI- staining, late apoptosis is defined by Annexin V+/PI+ staining, and necrosis is defined by Annexin V-/PI+ staining.

\subsection{Cell Migration Analyses}

A549, H1975, and HCC827 cell migration were evaluated by the scratch wound assay. Briefly, the cell lines were seeded on 6-well plates. After $24 \mathrm{~h}$, scratch wounds were created with $1000 \mu \mathrm{L}$ pipette tips on the pre-seeded confluent cells. After scratch wound induction, the culture was washed with PBS and replaced by a fresh medium containing increasing concentrations of EGCG $(30,70$, and $90 \mu \mathrm{M})$. Photomicrographs were taken at time 0 (immediately following the scratch wound), 24, 48, and $72 \mathrm{~h}$. The wound gaps were measured by ImageJ (version 1.47; NIH, Bethesda, MD, USA). The percentage migration was calculated by the average area reduction at 24,48 , and $72 \mathrm{~h}$ as compared to time 0 . Every well had 5 scratch wounds.

\subsection{Western Blot}

Cells were lysed with RIPA buffer ( $50 \mathrm{mM}$ Tris- $\mathrm{HCl}$ pH 8.0, $150 \mathrm{mM} \mathrm{NaCl}, 2 \mathrm{mM}$ EDTA, $0.5 \%$ Triton X-100) containing protease inhibitor cocktail (Sigma-Aldrich, P8340) on ice for $40 \mathrm{~min}$ and centrifugated at $12,000 \times \mathrm{g}$ for $10 \mathrm{~min}$ at $4{ }^{\circ} \mathrm{C}$. Supernatants were collected and protein concentration was determined by the Bradford assay. Equal amounts of denatured lysates $(20 \mu \mathrm{g})$ were separated on $4-20 \%$ precast SDS-PAGE system (Bio-Rad) and then transferred onto immunoblot PVDF membrane. The membrane was blocked with EveryBlot blocking buffer (Bio-Rad) for $5 \mathrm{~min}$ at $25^{\circ} \mathrm{C}$. After blotting, the membrane was cropped at the height of the protein of interest before being incubated with the specific antibody. Several antibodies can be visualized in the same run and the GAPDH is the same for all. The cropped blots were incubated with rabbit monoclonal antibodies (Cell Signaling Technology) against mTOR (\#2983), phospho-mTOR (Ser2448) (\#55336), STAT3 (\#4904), phospho-STAT3 (Tyr705) (\#9145), p38 (\#8690), and phospho-p38 MAPK (Thr180/Tyr182) (\#9211) at $4{ }^{\circ} \mathrm{C}$ overnight. All antibodies were diluted at a 1:2000 ratio. Mouse monoclonal anti-vinculin (1:300, Invitrogen, MA5-11690) was incubated for $1 \mathrm{~h}$ at R.T. All membranes were washed three times with TBST for $10 \mathrm{~min}$ and incubated with specific horseradish peroxidase (HRP)-conjugated secondary antibodies in accordance with the manufacturer's instructions for $1 \mathrm{~h}$ at R.T. Membranes were developed with enhanced SuperSignal ${ }^{\mathrm{TM}}$ west pico plus chemiluminescent substrate (Thermo Fisher Scientific) and optical densities 
were analyzed by ChemiDoc ${ }^{\mathrm{TM}}$ gel imaging system (Bio-Rad) and analyzed using ImageJ (version 1.47; NIH, Bethesda, MD). As an internal control for protein loading, membranes were reprobed with rabbit monoclonal GAPDH antibody (Cell Signaling Technology \#2118) for $1 \mathrm{~h}$.

\subsection{Statistical Analyses}

Data are presented as mean \pm S.D. (standard deviation). Statistical comparison of differences among groups of data was carried out using one-way analysis of variance (ANOVA), followed by Tukey's post hoc test using GraphPad Prism. Values of $p<0.05$ were considered statistically significant and values of $p<0.01$ were considered highly significant.

\section{Conclusions}

The effect of EGCG is NSCLC type-specific. The EGFR signaling pathway inhibition seems to be directly correlated to the ability of EGCG to influence the phosphorylation status of EGFR. In fact, in the H1975 cell line, in which EGCG is not able to inhibit EGFR phosphorylation, no changes are observed in the phosphorylation status of mTOR, MAPK38, and STAT3. In the other two cell lines the EGFR inhibition results instead in the alteration of the phosphorylation of these proteins. However, further studies need to be performed to assess whether EGCG directly inhibits the EGFR-mediated signaling pathway. The cells in which this inhibition occurs (A549 and HCC827) appear to be the most EGCG-sensitive NSCLC cells. In addition, EGCG also induces apoptosis in H1975 cells indicating that catechin acts by modulation of other pathways. In all NSCLC analyzed, EGCG treatment reduces cell migration and induces changes in vinculin and meta-vinculin expression. Overall, this makes the EGCG a potential adjuvant drug for lung cancer therapy.

Supplementary Materials: Multiple exposures of Western blot analysis are available online at https:/ / www.mdpi.com/article/10.3390/ijms222111833/s1.

Author Contributions: C.M., L.C., E.L. and T.A.; data curation, E.L. and G.M.; funding acquisition, C.M. and R.G.; investigation, C.M. and L.C.; methodology, C.M., L.C. and T.A.; project administration, C.M.; resources, G.M., R.G. and T.A.; software, E.L. and R.G.; supervision, R.G. and T.A.; validation, C.M.; writing —original draft, C.M.; writing—review and editing, L.C., E.L., G.M. and T.A. All authors have read and agreed to the published version of the manuscript.

Funding: This research was supported by AIRC (Associazione Italiana Per La Ricerca Sul Cancro), providing a postdoctoral research grant No. 25234 (two years fellowship) for the year 2021-2022 (C.M.).

Institutional Review Board Statement: Not applicable.

Informed Consent Statement: Not applicable.

Data Availability Statement: Not applicable.

Conflicts of Interest: The authors declare no conflict of interest.

\section{References}

1. Ferlay, J.; Soerjomataram, I.; Dikshit, R.; Eser, S.; Mathers, C.; Rebelo, M.; Parkin, D.M.; Forman, D.; Bray, F. Cancer incidence and mortality worldwide: Sources, methods and major patterns in GLOBOCAN 2012. Int. J. Cancer 2015, 136, E359-E386. [CrossRef] [PubMed]

2. Zhang, Y.L.; Yuan, J.Q.; Wang, K.F.; Fu, X.H.; Han, X.R.; Threapleton, D.; Yang, Z.Y.; Mao, C.; Tang, J.L. The prevalence of EGFR mutation in patients with non-small cell lung cancer: A systematic review and meta-analysis. Oncotarget 2016, 7, 78985-78993. [CrossRef]

3. Lynch, T.J.; Bell, D.W.; Sordella, R.; Gurubhagavatula, S.; Okimoto, R.A.; Brannigan, B.W.; Harris, P.L.; Haserlat, S.M.; Supko, J.G.; Haluska, F.G.; et al. Activating mutations in the epidermal growth factor receptor underlying responsiveness of non-small-cell lung cancer to gefitinib. N. Engl. J. Med. 2004, 350, 2129-2139. [CrossRef]

4. Hynes, N.E.; Lane, H.A. ERBB receptors and cancer: The complexity of targeted inhibitors. Nat. Rev. Cancer 2005, 5, 341-354. [CrossRef] [PubMed]

5. Caswell, P.T.; Chan, M.; Lindsay, A.J.; McCaffrey, M.W.; Boettiger, D.; Norman, J.C. Rab-coupling protein coordinates recycling of alpha5beta1 integrin and EGFR1 to promote cell migration in 3D microenvironments. J. Cell Biol. 2008, 183, 143-155. [CrossRef] [PubMed] 
6. Carcereny, E.; Moran, T.; Capdevila, L.; Cros, S.; Vila, L.; de Los Llanos Gil, M.; Remon, J.; Rosell, R. The epidermal growth factor receptor (EGRF) in lung cancer. Transl. Respir. Med. 2015, 3, 1. [CrossRef] [PubMed]

7. Katakowski, M.; Zheng, X.; Jiang, F.; Rogers, T.; Szalad, A.; Chopp, M. MiR-146b-5p suppresses EGFR expression and reduces in vitro migration and invasion of glioma. Cancer Investig. 2010, 28, 1024-1030. [CrossRef]

8. Ahsan, A. Mechanisms of Resistance to EGFR Tyrosine Kinase Inhibitors and Therapeutic Approaches: An Update. Adv. Exp. Med. Biol. 2016, 893, 137-153. [CrossRef]

9. Mok, T.S.; Wu, Y.L.; Thongprasert, S.; Yang, C.H.; Chu, D.T.; Saijo, N.; Sunpaweravong, P.; Han, B.; Margono, B.; Ichinose, Y.; et al. Gefitinib or carboplatin-paclitaxel in pulmonary adenocarcinoma. N. Engl. J. Med. 2009, 361, 947-957. [CrossRef]

10. Camidge, D.R.; Pao, W.; Sequist, L.V. Acquired resistance to TKIs in solid tumours: Learning from lung cancer. Nat. Rev. Clin. Oncol. 2014, 11, 473-481. [CrossRef]

11. Chen, L.Y.; Molina-Vila, M.A.; Ruan, S.Y.; Su, K.Y.; Liao, W.Y.; Yu, K.L.; Ho, C.C.; Shih, J.Y.; Yu, C.J.; Yang, J.C.; et al. Coexistence of EGFR T790M mutation and common activating mutations in pretreatment non-small cell lung cancer: A systematic review and meta-analysis. Lung Cancer 2016, 94, 46-53. [CrossRef]

12. Minnelli, C.; Galeazzi, R.; Laudadio, E.; Amici, A.; Rusciano, D.; Armeni, T.; Cantarini, M.; Stipa, P.; Mobbili, G. Monoalkylated Epigallocatechin-3-gallate (C18-EGCG) as Novel Lipophilic EGCG Derivative: Characterization and Antioxidant Evaluation. Antioxidants 2020, 9, 208. [CrossRef] [PubMed]

13. Du, G.J.; Zhang, Z.; Wen, X.D.; Yu, C.; Calway, T.; Yuan, C.S.; Wang, C.Z. Epigallocatechin Gallate (EGCG) is the most effective cancer chemopreventive polyphenol in green tea. Nutrients 2012, 4, 1679-1691. [CrossRef] [PubMed]

14. Lecumberri, E.; Dupertuis, Y.M.; Miralbell, R.; Pichard, C. Green tea polyphenol epigallocatechin-3-gallate (EGCG) as adjuvant in cancer therapy. Clin. Nutr. 2013, 32, 894-903. [CrossRef] [PubMed]

15. Almatroodi, S.A.; Almatroudi, A.; Khan, A.A.; Alhumaydhi, F.A.; Alsahli, M.A.; Rahmani, A.H. Potential Therapeutic Targets of Epigallocatechin Gallate (EGCG), the Most Abundant Catechin in Green Tea, and Its Role in the Therapy of Various Types of Cancer. Molecules 2020, 25, 3146. [CrossRef] [PubMed]

16. Ma, Y.C.; Li, C.; Gao, F.; Xu, Y.; Jiang, Z.B.; Liu, J.X.; Jin, L.Y. Epigallocatechin gallate inhibits the growth of human lung cancer by directly targeting the EGFR signaling pathway. Oncol. Rep. 2014, 31, 1343-1349. [CrossRef]

17. Meng, J.; Chang, C.; Chen, Y.; Bi, F.; Ji, C.; Liu, W. EGCG overcomes gefitinib resistance by inhibiting autophagy and augmenting cell death through targeting ERK phosphorylation in NSCLC. OncoTargets Ther. 2019, 12, 6033-6043. [CrossRef] [PubMed]

18. Chen, B.H.; Hsieh, C.H.; Tsai, S.Y.; Wang, C.Y.; Wang, C.C. Anticancer effects of epigallocatechin-3-gallate nanoemulsion on lung cancer cells through the activation of AMP-activated protein kinase signaling pathway. Sci. Rep. 2020, 10, 5163. [CrossRef] [PubMed]

19. Sun, K.K.; Zhong, N.; Yang, Y.; Zhao, L.; Jiao, Y. Enhanced radiosensitivity of NSCLC cells by transducer of erbB2.1 (TOB1) through modulation of the MAPK/ERK pathway. Oncol. Rep. 2013, 29, 2385-2391. [CrossRef] [PubMed]

20. Akca, H.; Tani, M.; Hishida, T.; Matsumoto, S.; Yokota, J. Activation of the AKT and STAT3 pathways and prolonged survival by a mutant EGFR in human lung cancer cells. Lung Cancer 2006, 54, 25-33. [CrossRef]

21. Sordella, R.; Bell, D.W.; Haber, D.A.; Settleman, J. Gefitinib-sensitizing EGFR mutations in lung cancer activate anti-apoptotic pathways. Science 2004, 305, 1163-1167. [CrossRef] [PubMed]

22. Janmaat, M.L.; Kruyt, F.A.; Rodriguez, J.A.; Giaccone, G. Response to epidermal growth factor receptor inhibitors in non-small cell lung cancer cells: Limited antiproliferative effects and absence of apoptosis associated with persistent activity of extracellular signal-regulated kinase or Akt kinase pathways. Clin. Cancer Res. 2003, 9, 2316-2326. [PubMed]

23. Yeung, Y.T.; Yin, S.; Lu, B.; Fan, S.; Yang, R.; Bai, R.; Zhang, C.; Bode, A.M.; Liu, K.; Dong, Z. Losmapimod Overcomes Gefitinib Resistance in Non-small Cell Lung Cancer by Preventing Tetraploidization. EBioMedicine 2018, 28, 51-61. [CrossRef]

24. Kedrin, D.; van Rheenen, J.; Hernandez, L.; Condeelis, J.; Segall, J.E. Cell motility and cytoskeletal regulation in invasion and metastasis. J. Mammary Gland Biol. Neoplasia 2007, 12, 143-152. [CrossRef]

25. Lu, Z.; Jiang, G.; Blume-Jensen, P.; Hunter, T. Epidermal growth factor-induced tumor cell invasion and metastasis initiated by dephosphorylation and downregulation of focal adhesion kinase. Mol. Cell Biol. 2001, 21, 4016-4031. [CrossRef] [PubMed]

26. Yu, Q.; Xu, L.; Chen, L.; Sun, B.; Yang, Z.; Lu, K. Vinculin expression in non-small cell lung cancer. J. Int. Med. Res. 2020, 48, 300060519839523. [CrossRef] [PubMed]

27. Izard, T.; Brown, D.T. Mechanisms and Functions of Vinculin Interactions with Phospholipids at Cell Adhesion Sites. J. Biol. Chem. 2016, 291, 2548-2555. [CrossRef] [PubMed]

28. Kawakami, K.; Fujita, Y.; Kato, T.; Mizutani, K.; Kameyama, K.; Tsumoto, H.; Miura, Y.; Deguchi, T.; Ito, M. Integrin beta4 and vinculin contained in exosomes are potential markers for progression of prostate cancer associated with taxane-resistance. Int. J. Oncol. 2015, 47, 384-390. [CrossRef] [PubMed]

29. Sun, Z.; Liu, F. Association of Nox1 and vinculin with colon cancer progression. Cancer Investig. 2013, 31, 273-278. [CrossRef] [PubMed]

30. Minnelli, C.; Laudadio, E.; Mobbili, G.; Galeazzi, R. Conformational Insight on WT- and Mutated-EGFR Receptor Activation and Inhibition by Epigallocatechin-3-Gallate: Over a Rational Basis for the Design of Selective Non-Small-Cell Lung Anticancer Agents. Int. J. Mol. Sci. 2020, 21, 1721. [CrossRef]

31. Genheden, S.; Ryde, U. The MM/PBSA and MM/GBSA methods to estimate ligand-binding affinities. Expert Opin. Drug Discov. 2015, 10, 449-461. [CrossRef] 
32. Olson, T.M.; Illenberger, S.; Kishimoto, N.Y.; Huttelmaier, S.; Keating, M.T.; Jockusch, B.M. Metavinculin mutations alter actin interaction in dilated cardiomyopathy. Circulation 2002, 105, 431-437. [CrossRef] [PubMed]

33. Janssen, M.E.; Liu, H.; Volkmann, N.; Hanein, D. The C-terminal tail domain of metavinculin, vinculin's splice variant, severs actin filaments. J. Cell. Biol. 2012, 197, 585-593. [CrossRef]

34. Rudiger, M.; Korneeva, N.; Schwienbacher, C.; Weiss, E.E.; Jockusch, B.M. Differential actin organization by vinculin isoforms: Implications for cell type-specific microfilament anchorage. FEBS Lett. 1998, 431, 49-54. [CrossRef]

35. Relat, J.; Blancafort, A.; Oliveras, G.; Cufi, S.; Haro, D.; Marrero, P.F.; Puig, T. Different fatty acid metabolism effects of (-)-epigallocatechin-3-gallate and C75 in adenocarcinoma lung cancer. BMC Cancer 2012, 12, 280. [CrossRef] [PubMed]

36. Bjornsti, M.A.; Houghton, P.J. The TOR pathway: A target for cancer therapy. Nat. Rev. Cancer 2004, 4, 335-348. [CrossRef] [PubMed]

37. Abraham, R.T.; Gibbons, J.J. The mammalian target of rapamycin signaling pathway: Twists and turns in the road to cancer therapy. Clin. Cancer Res. 2007, 13, 3109-3114. [CrossRef] [PubMed]

38. Zimmer, S.; Kahl, P.; Buhl, T.M.; Steiner, S.; Wardelmann, E.; Merkelbach-Bruse, S.; Buettner, R.; Heukamp, L.C. Epidermal growth factor receptor mutations in non-small cell lung cancer influence downstream Akt, MAPK and Stat3 signaling. J. Cancer Res. Clin. Oncol. 2009, 135, 723-730. [CrossRef] [PubMed]

39. Li, R.; Hu, Z.; Sun, S.Y.; Chen, Z.G.; Owonikoko, T.K.; Sica, G.L.; Ramalingam, S.S.; Curran, W.J.; Khuri, F.R.; Deng, X. Niclosamide overcomes acquired resistance to erlotinib through suppression of STAT3 in non-small cell lung cancer. Mol. Cancer 2013, 12, 2200-2212. [CrossRef] [PubMed]

40. Codony-Servat, C.; Codony-Servat, J.; Karachaliou, N.; Molina, M.A.; Chaib, I.; Ramirez, J.L.; de Los Llanos Gil, M.; Solca, F.; Bivona, T.G.; Rosell, R. Activation of signal transducer and activator of transcription 3 (STAT3) signaling in EGFR mutant non-small-cell lung cancer (NSCLC). Oncotarget 2017, 8, 47305-47316. [CrossRef]

41. Chaib, I.; Karachaliou, N.; Pilotto, S.; Codony Servat, J.; Cai, X.; Li, X.; Drozdowskyj, A.; Servat, C.C.; Yang, J.; Hu, C.; et al. Co-activation of STAT3 and YES-Associated Protein 1 (YAP1) Pathway in EGFR-Mutant NSCLC. J. Natl. Cancer Inst. 2017, 109, djx014. [CrossRef] [PubMed]

42. Minnelli, C.; Laudadio, E.; Galeazzi, R.; Rusciano, D.; Armeni, T.; Stipa, P.; Cantarini, M.; Mobbili, G. Synthesis, Characterization and Antioxidant Properties of a New Lipophilic Derivative of Edaravone. Antioxidants 2019, 8, 258. [CrossRef] [PubMed] 